\title{
ДЕЩО ПРО УКРАЇНСЬКІ ПРІЗВИЩА ТА ЇХНЮ ДЕНАЦІОНАЛІЗАЦІЮ
}

Колоїз Ж. В. Дещо про українські прізвища та їхню денаціоналізацію.

У статті йде мова про українські прізвища, їхні характерні фонетичні, словотвірні та лексичні особливості; установлено мотиваційні відношення між дериваційною базою та похідним антропонімом; основний акцент зроблено на патронімічні прізвища та прізвища, пов'язані з професійною діяльністю; виявлено шляхи їхньої денаціоналізації.

Ключові слова: прізвище, антропонім, словотвірні особливості, похідна одиниця, дериваційна база, денаціоналізація.

Колоиз Ж. В. Несколько слов об украинских фамилиях и их денационализации.

В статье рассматриваются украинские фамилии, их характерные фонетические, словообразовательные, лексические особенности; устанавливаются мотивационные отношения между деривационной базой и антропонимом; основное внимание акцентируется на патронимических фамилиях и фамилиях, связанных с профессиональной деятельностью; выявлены пути их денационализации.

Ключевые слова: фамилия, антропоним, словообразовательные особенности, мотивированная единица, деривационная база, денационализация.

Koloiz Z. V. A few words about Ukrainian surnames and their denationalization.

The article deals with Ukrainian surnames, their distinctive phonetic, word-building, lexical features. The motivational relations between derivative base and anthroponomy are established. Emphasis is laid on the patronymic surnames and family names associated with professional activities. The ways of Ukrainian surname denationalization are identified.

Key words: surname, anthroponomy, word-building features, motivational unit, derivative base, denationalization.

Прізвище є частиною історії народу, його мови, культури, релігії, вірувань, праці, побуту, світогляду, соціального становища і т. ін. I це цілком закономірно, адже сама лексема використовується для означення такого поняття, як «найменування особи, набуте при народженні або вступі у шлюб, що передається від покоління до покоління і вказує на спорідненість» [1, с. 959] (пор.: прізвище < прозъвнщє, прозъвнсько «найменування, яке іноді дається людині, крім справжнього прізвища та імені, і вказує на яку-небудь рису іiі характеру, зовнішності, діяльності і звичок»). Коріння українського прізвища як офіційної назви сягає XIV-XV ст., їхня поява зумовлена розбудовою законодавства, що вимагало передусім точності в оформленні різних юридичних документів (купівля / продаж майна, заповіти про спадок тощо). Спадковими родовими прізвищами наділялися здебільшого представники тодішньої суспільної верхівки.

Більшість українців отримали свої прізвищеві найменування вже в XVII ст., зокрема після того, як у 1632 році київський митрополит Петро Могила доручив парафіяльним священикам вести метрики новонароджених, одружених і померлих. Такий історичний факт свідчить 
про те, що українське прізвище є чи не найдавніше в Свропі (пор.: французи почали масово прізвищуватися згідно 3 наказом імператора Наполеона Першого на початку XIX ст.; російські селяни отримали свої прізвища після Реформи 1861 року). ${ }^{1}$

Прізвищева підсистема української антропоніміки досить строката, характеризується специфічними фонетичними, лексичними, словотвірними, морфологічними особливостями, які неодноразово ставали предметом зацікавлення вітчизняних науковців.

Більшість дослідників одностайні в тому, що можна чітко виокремити ряд так званих формальних показників, які свідчать про українське коріння того чи того прізвища. Не викликає жодних сумнівів те, що саме до таких диференційних ознак належать суфікси -енк(о), -ук (-юк), -чук (дехто 3 науковців нараховує понад 50 формантів, що використовуються для продукування антропонімічних назв). Найчастіше для продукування відповідних похідних застосовували дериваційну базу, співвідносну з іменем батька, глави родини. Причому суфіксом -yк (-юк) послуговувалися тоді, коли йшлося про старшу в родині дитину (Власюк $\leftarrow$ Влас; Гаврилюк $\leftarrow$ Гаврило; Гнатюк $\longleftarrow$ Гнат; Карпюк $\leftarrow$ Карпо Микитюк $\longleftarrow$ Микита; Стефранюк $\longleftarrow$ Стефран тощо), суфікс -енк(о) використовувався для прізвищування молодшого сина (Устименко ᄂ Устим; Григоренко $\leftarrow$ Григор; Макаренко $\longleftarrow$ Макар; Марченко $\leftarrow$ Марко;

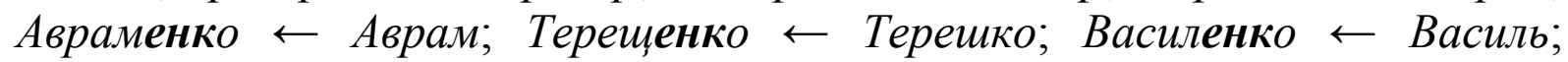
Герасименко $\leftarrow$ Герасим; Свтушенко $\leftarrow$ Свтух; Антоненко $\leftarrow$ Антон; Онищенко $\leftarrow$ Онисько; Семененко $\leftarrow$ Семен; Яременко $\leftarrow$ Ярема;

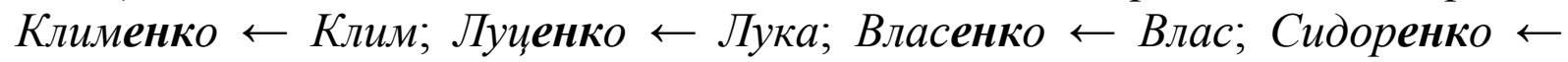
Сидір; Костенко $\leftarrow$ Костя; Ярошенко $\leftarrow$ Ярош тощо). Найменування 3 формантом -енк(о), що виник через поєднання суфіксів -ен(я) і -к(о), мали первісне так зване демінутивне значення, тобто позначали малих, недорослих істот: Костенко - «малий Костя; син Кості», Семененко «малий Семен; син Семена».

У в першому, i в другому разі подібні антропоніми можуть мати модифіковану структуру, що зумовлено передусім історичними фонетичними процесами як похідного утворення, так і дериваційної бази. Так, скажімо, прізвище Вавринюк вибудувалося на основі чоловічого ім'я Лаврін (Лаврентій) (лат. Laurentius < Laurens - «лаврентієць», «житель міста Лаврента»); унаслідок регресивної дистантної асиміляції передньоязиковий [л] модифікується на губно-губний [в], а відтак номени на зразок Вавринюк, Лавринюк, Лавриненко, Лавринович і т. ін. є генетично спорідненими. Етимологічно спорідненими $є$ також прізвища на зразок

1 Єдиним народом Європи, у якого до сьогодні немає прізвищ як таких, є ісландці: новонароджена дитина номінується через ім'я батька, наприклад, Петерсен - «син Петера», Петердоттір - «донька Петера» (пор.: за таким зразком спродуковане й прізвище українського письменника Майка Йогансена, де Йогансен - «син Йогана»). 
Степанюк, Стефанюк, Штепанюк, що $є$ фонетичними варіантами грецького особового імені Stephanos < stephanos - «вінок»; останній варіант, очевидно, зумовлений впливом польської мови (пор.: Stefan, Szćzepan). Фонетичні варіанти українських прізвищ Ігнатюк, Ігнатенко мають безпосередній стосунок до особового імені Гнат, яке через старослов'янську Иг'ънатин запозичено з грецької Ignatius. Кондратенко $\leftarrow$ Кіндрат; Самойленко $\leftarrow$ Самійло демонструють незакономірний фонетичний процес, зокрема відсутність переходу етимологічного [o] в [i] в закритих складах. Українське прізвище Гапоненко співвідносне 3 особовим іменем Гапон $<$ Агапон $<$ Агафон $<3$ грецького agathon - «благо, добро». Калениченко $\leftarrow$ Каленик (з грецького Kallinikos - «прекрасний переможець», де kallos - «краса» і nikē- «перемога»).

Чимало прізвищ із суфіксом -енк(о) було спродуковано не на базі інваріантних форм особових чоловічих імен, а на основі їхніх стилістичних варіантів, що вже мали в своїй структурі суфікси здебільшого пестливості: Дмитриченко $\leftarrow$ Дмитрик $\leftarrow$ Дмитро; Демченко $\leftarrow$ Демко (Дем'янко) $\leftarrow$ Дем'ян; Юрченко $\leftarrow$ Юрко $\leftarrow$ Юр; Зінченко $\leftarrow$ Зінко $\leftarrow$ Зіновій; Михальченко $\leftarrow$ Михалько $\leftarrow$ Михайло; Іванченко $\leftarrow$ Іванко $\leftarrow$ Іван; Савченко $\leftarrow$ Савк $а \leftarrow$ Сава; Миколайченко $\leftarrow$ Миколайко $\leftarrow$ Миколай.

3 іменами по батькові генетично пов'язані прізвища на -ич, -ович, -евич, що побутували в середовищі шляхти і міщанства, закріпилися передусім серед привілейованих верств населення: Антонич $\leftarrow$ Антон; Хомич $\leftarrow$ Хома; Силич $\leftarrow$ Сила; Кузьмич $\leftarrow$ Кузьма; Прокопович $\leftarrow$ Прокіп; Максимович $\leftarrow$ Максим; Давидович $\leftarrow$ Давид; Трохимович $\leftarrow$ Трохим; Федькович $\leftarrow$ Федько; Гриневич $\leftarrow$ Гринько (Григорій); Зінкевич $\leftarrow$ Зінко (Зіновій). Навіть сама загальна назва перейшли до розряду антропонімів: Шляхтич $\leftarrow$ иляхтич - «особа, що належала до шляхти дрібного дворянства колишньої феодальної Польщі, а згодом i дореволюційної України, Білорусі, Литви» (пор. також: Мімук, Міщенко). Подібною соціальною маркованістю вирізнялися й патронімічні прізвища 3 суфіксом -ськ(ий): Варнавський $\leftarrow$ Варнава (гр. Barnabas < д.-євр. BarNaba - «син утіхи»); Cтепанівський $\leftarrow$ Cтепан; Петрівський (Петровський $\leftarrow$ Петро; Томашівський $($ Томамевський $\leftarrow$ Томаш (пол. Tomasz), де Toмаш споріднене з українським Хома $(<$ гр. Thomas «близнюк»). Різноманітні варіації особового імені (Хома, Тома, Фома, а також похідні з пестливими та згрубілими суфіксами) зумовили цілу низку прізвищевих назв: Тома, Томак, Томаменко, Томашкевич, Томамук, Томенко, Томенюк, Томилин, Томчук, Том'як, Хоменко, Хоменський, Хоминець, Хомкало, Хомко, Хомович, Хомчук, Хом'юк, Хом'як і т. ін. (останне доволі часто виводять від зооніма хом'як; у такому разі варто, мабуть, більш скрупульозно підходити до дослідження власного родоводу). 
Поширеним типом спадкового прізвищування були номени, що утворювалися від назв населених пунктів за допомогою того ж таки суфікса -ськ(ий) у різних фонетичних модифікаціях: Хорольський $\leftarrow$ Хорол; Пінський $\leftarrow$ Пінськ; Канівський $\leftarrow$ Канів; Хмельницький $\leftarrow$ Хмільник; Галицький $\leftarrow$ Галич тощо. Спадкові прізвища на -ськ(ий) були соціально маркованими, репрезентували шляхетне (Вишневецький, Винницький, Креховецький, Грушевський, Свідзінський) чи то ошляхетнене (Скоропадський, Сухомлинський, Коиюбинський, Попівський) походження і протиставлялися так званим «батьківським» і «вуличним» ${ }^{2}$. У першому разі пов'язувалися передусім із назвою маєтного володіння (населеного пункту): Вишневецький $\leftarrow$ м. Вишневець на Волині, що належало князям Вишневецьким; Винницький $\leftarrow$ м. Винники Львівської області (або ж м. Вінниця); Креховецький $\leftarrow$ с. Крехово на Жовківщині Львівської області (Іван Креховецький - шляхтич із Галичини, що виконував дипломатичні доручення Богдана Хмельницького); Хмельницький $\leftarrow$ м. Хмільник на Вінниччині i т. ін. В іншій ситуації - прізвища, очевидно, «трансформувалися» в XVII -XVIII ст. у час переходу козацької старшини до шляхетського стану (Скоропадський $\leftarrow$ Скоропад $\leftarrow$ скоропад (у південно-західних діалектах скоропадною називають швидку, прудку людину); Сухомлинський $\leftarrow$ Сухомлин $\leftarrow$ сухомлин (пор.: сухомельщина «плата за помел»); Коцюбинський $\leftarrow$ Коиююбин $\leftarrow$ Коцюба $\leftarrow$ коиюба «знаряддя у вигляді насадженого на держак залізного прута 3 розплесканим i загнутим кінцем для перемішування палива в печі й вигрібання з неї жару, попелу».

Подекуди дериваційною базою прізвищ слугували не чоловічі, а жіночі особові імена. Їхня поява була ситуативно зумовлена: після смерті чоловіка жінка перебирала на себе обов'язки глави сім'ї. Про такий факт свідчить хоч би висока продуктивність прізвищ на зразок Удовенко $\leftarrow$ удова (пор.: Удовиченко $\leftarrow$ удовиия). Причому до твірної основи додавалися найрізноманітніші суфікси: Мотренко, Мотрич $\leftarrow$ Мотря; Настенко, Настич $\leftarrow$ Настя; Ганненко, Ганнич $\leftarrow$ Ганна; Марусенко, Марусич, Марусяк $\leftarrow$ Маруся; Меланчук (Маланчук), Меланюк (Маланюк) $\leftarrow$ Меланія (Маланія); Софієнко, Софійчук $\leftarrow$ Софія; Катериненко, Катеринич, Катеринчук $\leftarrow$ Катерина; Параниця, Паранько, Парашук $[$ Парашчук $] \leftarrow$ Параня (Параска) $)^{3}$ т. ін.). Цікавими $є$ прізвища, утворені

\footnotetext{
${ }^{2}$ Поява спадкових «вуличних» прізвищ зумовлена насамперед узуалізацією прізвиськ, які були і $€$ невід’ємною рисою колоритного народного найменування. Їхній значеннєвий діапазон $€$ досить широким: тут закладена інформація про людину як особистість, про іiі звички, вдачу, побут і т. ін. (Безпояско, Голобородько, Рябошапка, Дзюба, Горбач, Мовчан, Кирпа, Щербак, Стогній, Смаглій, Багрій тощо).

${ }^{3}$ На думку сучасних дослідників, формант -енк(о) засвідчує здебільшого східноукраїнську традицію прізвищування, а -чук - західноукраїнську (пор. похідні від чоловічих імен по батькові: Никончук $\leftarrow$ Никон; Зосимчук $\leftarrow$ Зосим; Минчук $\leftarrow$ Мина; Гордійчук $\leftarrow$ Гордій; Сергійчук $\leftarrow$ Сергій; Пархомчук $\leftarrow$ Пархом; Оверчук $\leftarrow$ Оверко; Герасимчук $\leftarrow$ Герасим;
} 
від жіночих прізвиськ, співвідносних із найменуванням чоловіка: Панчишин $\leftarrow$ Панчих $а \leftarrow$ Панько; Романишин $\leftarrow$ Романиха $\leftarrow$ Роман; Степанишин $\leftarrow$ Степаниха $\leftarrow$ Степан; Петришин $\leftarrow$ Петриха $\leftarrow$ Петро тощо. Суфікс -ин, який вказував на належність особі, в окремих ситуаціях додавався й безпосередньо до основи імені (Феська $\rightarrow$ Фещъин; Ганя $\rightarrow$ Ганин; Марина $\rightarrow$ Маринин). Прізвища на зразок Ганін, Маринін і т. ін. ілюструють один із багатьох процесів денаціоналізації.

Генетична систематизація прізвищевих номенів дає змогу виокремити чимало тематичних груп, з-поміж яких заслуговують на увагу передусім:

1. Номени, що вказують чи то на етнічну належність, чи то на відповідний стосунок до того чи того етносу: утворені як унаслідок

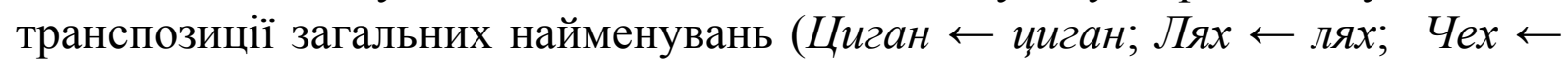

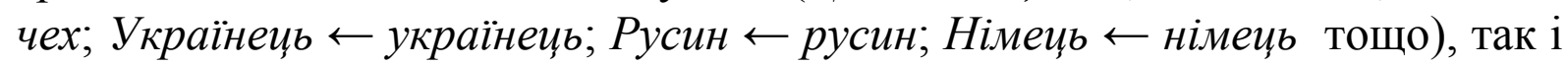
в результаті додавання відповідних формантів (Циганенко, Циганчук; Ляменко, Лящук [Л'ашчук], Ляшко; Німенко, Німченко, Німчук; Турченко, Турчин; Татаренко, Татарчук тощо). 3-поміж них вирізняються похідні й від так званих неофіційних назв: Хохол $\leftarrow$ хохол - «зневажлива назва

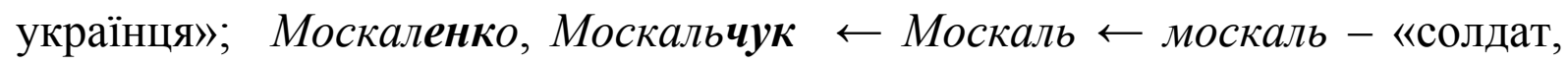
який відслужив у царській армії; росіянин». Етимологія деяких з них не $є$ прозорою, як-от, скажімо, прізвище Угрин вказує на стосунок до угорського етносу, однак могло використовуватися й для означення чи то закарпатця, чи то хорвата; Волошин, з одного боку, засвідчує причетність до румунського етносу або до пов'язаної з ним відповідної території, сприяє утворенню таких антропонімів, як Волошенко, Волошук тощо, 3 іншого, - може вказувати на суб'єкта волоського права («волоське право»середньовічний синонім «римського права»; пор.: Волощук [Волошчук] волошук - «суб’єкт волоського права»). Номен Литвин на перший погляд нібито має прозору мотивацію: його дериваційною базою послужив топонім Литва. Щоправда, для українців литвин асоціювався передусім із білоруським народом. А похідні на зразок Литвиненко, Литвинчук активно використовувалися для позначення поняття «син литвина, білоруса». Деякі з подібних прізвищевих назв можуть мати подвійну (а то й потрійну) мотивацію: Німчук («син німця») $\longleftarrow$ німецьь - «той, хто $є$ вихідцем із Німеччини»; Німчук («син німця») $\longleftarrow$ німещь - «перен. той, хто говорить незрозумілою мовою; зайшлий іноземець»; Німчук («син німого») $\leftarrow$ німий - «той, хто позбавлений здатності говорити».

2. Номени, що вказують на стосунок до місця проживання, засвідчують транспозицію іменників загальної семантики, спродукованих

Климчук $\leftarrow$ Клим; Остапчук $\leftarrow$ Oстап; Панчук $\leftarrow$ Панько (Опанас) тощо). Крім того, у західноукраїнській традиції активністю вирізнялися й похідні з суфіксами -к, -ець ( Силко Сила; Валько $\leftarrow$ Валя; Данилко $\leftarrow$ Данило; Іванещь $\leftarrow$ Іван; Романещь $\leftarrow$ Роман; Наумещь $\leftarrow$ Наум; Назарець $\leftarrow$ Назар; Степанець $\leftarrow$ Степан тощо). 
чи то на основі назв міст, чи то на основі назв неофіційних територій (Волинець $\leftarrow$ волинець $\leftarrow$ Волинь; Полтавець $\leftarrow$ полтавець $\leftarrow$ Полтава; Уманець $\leftarrow$ уманець $\leftarrow$ Умань; Хоролецьь $\leftarrow$ хоролець $\leftarrow$ Хорол; Полішук $\leftarrow$ полішук [полішчук] $\longleftarrow$ Полісся. Іноді за дериваційну базу слугує не топонімічна, а гідронімічна (загальна / власна) назва, а то й узагалі будьякий іменник із конкретною просторовою семантикою: Загребельний («той, хто проживає за греблею») $\longleftarrow$ гребля; Задорожний («той, хто проживає за дорогою») $\longleftarrow$ дорога; Задунайський («той, що проживає за

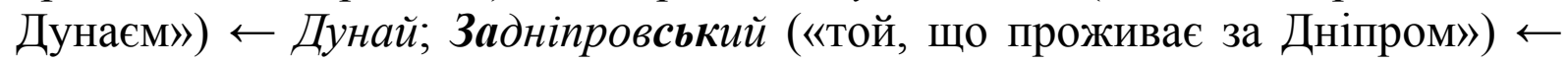
Дніпро тощо).

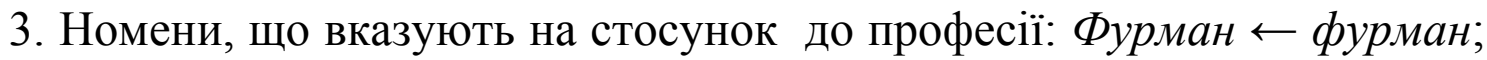

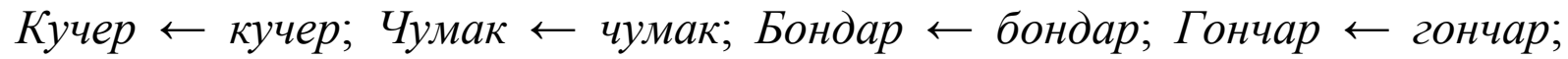

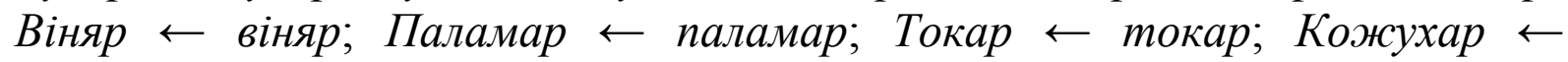

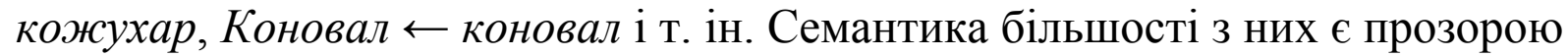
і зрозумілою. Деякі з прізвищ співвідносні з однією й тією ж професійною діяльністю, як-от, скажімо, фурман і кучер, де перша лексема запозичена 3 німецької через посередництво польської мови furman (fura - «підвода, хура»), інша - 3 німецької Kutscher $<$ Kutsche - «карета, візок» ${ }^{4}$. Частина у процесі історичного розвитку зазнала відповідних модифікацій. Наприклад, прізвища Бондар і Боднар отримували спадкоємці «майстрів із виготовлення діжок, дерев'яних відер». Велика діжка 3 кришкою називалася бодня, звідси, відповідно, й імення людини, що займалися їхнім виготовленням, - боднар. У формах бондар, Бондар і похідних від них (Бондаренко, Бондарчук і т. ін.) засвідчене явище метатези дн $\rightarrow$ нд. Прізвище Гончар спродуковано на базі загальної назви гончар - «майстер, який виготовляє посуд та інші вироби із глини», етимологічно спорідненої з іменником горня (пор. староукр.: гърнь чарь). Українське прізвище Віняр немає жодного стосунку до іменника вино: людина, що займалася виготовленням такого напою, називалася винокуром, винником (пор.: Винокур, Винник, Винничук, Винниченко тощо). Дериваційною базою послужило, очевидно, дієслово вінити - «наділяти посагом», що утворилося на основі іменника віно (староукр. в $\mathbf{k ⿰ ㇒ - ~}-$ «придане, посаг»). Етимологічно спорідненими є прізвища Пономар і Паламар (а також похідні від них Пономарчук, Пономаренко, Паламарчук, Паламаренко і

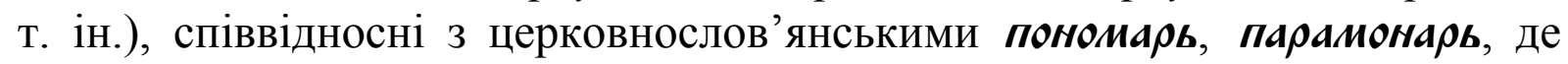
перше стабілізувалося в лексичній системі російської мови, інше (після різних фонетичних модифікацій) закріпилося лексичною системою української мови як паламар, однак в обох ситуаціях використовуються для позначення «служителя православної церкви, що допомагає священикові під час богослужіння».

\footnotetext{
${ }^{4}$ Прізвища, пов'язані з професійною діяльністю, представлені в усіх народів (пор.: укр. Коваль, рос. Кузнецов, англ. - Сміт, нім. - Шмідт, фр. - Лефевр, італ. - Ферере, груз. - Мчеделі).
} 
Чимало слів, що послужили для продукування прізвищ на основі професійної діяльності, поступово виходять 3 активного вжитку, замінюючись сучасними модними назвами. Однак прізвища залишаються, а їхнє декодування дає змогу зазирнути не лише в глибини нашої спільної історії, але й передусім дізнатися про своє коріння. Наприклад: Компанієць $\leftarrow$ компанієuь - «у XVII-XVIII ст. козак легкокінного козацького полку»; Золотар « золотар - «ювелір; той, хто покривав позолотою» (пор. золотник); Кушнір Ł кушнір - «той, хто вичиняв хутро зі шкури та шив хутряні вироби»; Бортник $\leftarrow$ бортник - «той, хто займався лісовим бджільництвом»; Гутник « гутник - «той, хто виробляв посуд та інші речі зі скла»; Гармаш Ł гармаш - «той, хто виготовляє і обслуговує гармати»; Грабар Ł грабар - «той, хто займається земляними роботами; землекоп» (нім. Gräber < graben - «копати»); Лимар Ł лимар - «той, хто виготовляв ремінну збрую»; Стельмах $\leftarrow$ стельмах - «той, хто виготовляв вози, сани, колеса». Ці та інші антропоніми послужили дериваційною базою для цілого ряду похідних: Золотаренко, Золотарчук, Бортниченко, Лимаренко, Лимарчук, Грабарчук, Стельмащук тощо.

Прізвища на зразок Лимаренко, Лимарчук, Римаренко, Римарчук є етимологічно спорідненими. Загальна назва лимар запозичена з німецької мови через польське посередництво Riemer < Riemen - «ремінь». Унаслідок дистантної дисиміляції дрижачий $[\boldsymbol{p}]$ змінюється на боковий $[\boldsymbol{\pi}]$. Подібне фонетичне явище спостерігається й у загальновідомому прізвищі Петлюра, яке здебільшого виводять від загальної назви петля. Більш прийнятною, на нашу думку, є позиція, згідно з якою це патронімічне прізвище, утворене за допомогою суфікса згрубілості (Петлюра < Петрура $\leftarrow$ Петро (пор. Степура $\leftarrow$ Cтепан; Сосюр $а \leftarrow$ Сосій і т. ін.).

Наявність фонетичних варіантів Стельмах і Штельмах пояснюється фонетичною адаптацією іншомовних запозичень, що послужили дериваційною базою: українське стельмах запозичене з німецької мови (Stellmacher < Stell - «місце; насад воза» + machen - «робити») через посередництво польської (stelmach - «колісник»).

3 однією професійною діяльністю пов’язуються прізвища Мельник і Мірошник (Мельниченко, Мельничук, Мірошниченко, Мірошничук).

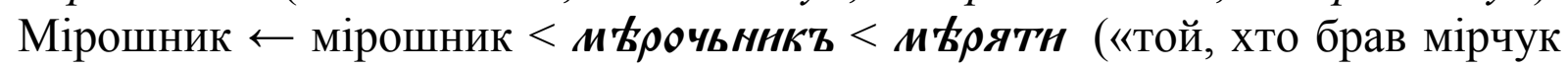
(міру зерна) за помел»). Особливістю прізвищ, пов'язаних із професійною діяльністю, $є$ те, що їхній формальний показник - суфікс -чук вирізняється полісемічністю: 3 одного боку похідні сприймається зі значенням «син того чи того майстра», з іншого, - як «учень того чи того майстра» (Ковальчук, Кравчук, Бондарчук, Крамарчук тощо).

Прізвище Коломиєцьь $\longleftarrow$ коломиєщзь - «солевар» закріпилося в українській традиції як Коломієць. Звуковий комплекс співзвучний із назвою міста Коломия, яке в епоху Середньовіччя було центром добування солі, що вивозилася на Придніпров'я. Власна ж назва Коломия пов'язана, 
очевидно, з апелятивом коломия - «глибока вибоїна, наповнена водою» (у буквальному розумінні «те, що миє колесо»). Сучасна форма вираження зазначеного прізвища, як і цілої низки інших, зумовлена, з одного боку, тими закономірними процесами, засвідченими в історії розвитку насамперед системи вокалізму, з іншого, - впливом російської мови. Таку незакономірну для української мови фонетичну особливість відображають такі відомі українські прізвища як, скажімо, Грінченко і Сімович (мало б бути Гринченко $\leftarrow$ Гринько; Симович $\leftarrow$ Cим (< гр. Simos < д.-євр. Sem «знатне ім'я», ім'я одного з синів Ноя). Денаціоналізацію, тобто втрату національного обличчя, засвідчують передусім ті українські прізвища, які мають виразні формальні показники своєї українськості (Ніколайченко замість Миколайченко (< Миколай); Удовіченко замість Удовиченко (< удовиия); Моісієнко замість Мойсеєнко (< Мойсей або ж Мусієнко ᄂ Мусій); Калініченко замість Калиниченко $(<$ Калиник $\leftarrow$ Калина); Міненко замість Миненко (< Мина); Літвіненко замість Литвиненко (< Литвин); Сіліч замість Силич (< Сила); Клімчук замість Климчук (<Клим). Згідно 3 нормами українського правопису у прізвищах на зразок Косиненко, Могилей, Дудник, Решетник, Пильник, Селиванов, Слизаров, Устинов, Новиков, Гнилуша і т. ін. має писатися буква $\boldsymbol{u}$, а не $\boldsymbol{i}$, яка позначає звук, що не пом'якшує приголосний, після якого вона стоїть, а це, відповідно, сприяє дотриманню орфоепічних норм. У багатьох подібних прізвищах представлені не властиві сучасній українській літературній мові антропонімічні суфікси, зокрема -нік, -ніч, -iк, -іч (у словотвірній системі української мови стабілізувалися суфікси -ник, -нuч, -ик, -ич). Суфікси -iк, -iч, -ін використовуються тоді, коли основа твірного слова закінчується приголосним [й] (Тимофї̈к, Гордїч, Софї̈н). Написання літери $\boldsymbol{u}$, а не $\boldsymbol{i}$ (у суфіксах -ик, -ич, -иц, -ищ) зберігається й у так званих іншомовних прізвищах (Голик, Котельников, Крутиков, Кулинич, Голицин, Палицин і т. ін.) [7, с. 112]. Така ж літера засвідчується й «у прізвищах, утворених від людських імен та загальних назв, спільних для української, російської та інших слов’янських мов» [7, с. 112] (пор.: Селиван, Слизар, Устин, могила, гнилий і т. ін.).

У зв'язку 3 цим варто, очевидно, згадати про таку фонетичну особливість староукраїнської системи вокалізму, як розрізнення голосного переднього ряду $[\boldsymbol{i}]$, що позначався літерою $\boldsymbol{u}$, та середнього ряду [u], що позначався літерою $\boldsymbol{k}$. Перший $з$ них, як і всі голосні переднього ряду староукраїнської мови, мав здатність пом'якшувати приголосні після яких стояв (снла, мняо «гарно», Gелнванъ, Устннъ, могнАа, гнняын тощо), інший, навпаки, займав позицію лише після твердого приголосного (сынъ, мылю). Унаслідок обниження артикуляції два названі звуки злилися в один $[\boldsymbol{u}]$ - голосний передньо-середнього ряду, високо-середнього піднесення. Для позначення нового звука на письмі не було спеціальної літери, що спричинило, так би мовити, «мішанину» в написанні традиційних літер $\boldsymbol{u}$ 
та $\boldsymbol{b}$, використовуваних для позначення звука, який утратив здатність пом'якшувати попередні приголосні.

Подекуди антропонімічні номени репрезентують кілька фонетичних процесів, які настільки затемнюють справжню етимологію прізвища, що встановлюються невластиві для відповідної назви мотиваційні відношення. Так, скажімо, на основі чоловічого імені Ничипір (Никифор) (гр. Nikēphoros < nikēphoros - «переможець») відповідно до норм українського словотворення та 3 використанням суфікса -енк(о) логічно мав би з'явитися антропонім Ничипоренко. Фонетичні варіації на зразок Нечипоренко, Нечипуренко і т. ін. засвідчують такі модифікації, як зближення ненаголошених $[\boldsymbol{u}] /[\boldsymbol{e}]$ та сильне «укання». Процес зближення чи то $[\boldsymbol{u}] /[\boldsymbol{e}]$, чи то $[\boldsymbol{e}] /[\boldsymbol{u}]$ маніфестують, очевидно, такі прізвища, як Лисечко, Лисевич. За такого звукового оформлення їхня семантика $є$ незрозумілою. Народна етимологія, що витлумачує ці антропоніми через стосунок до відповідної лексеми 3 атрибутивною семантикою, не відтворює реальної картини їхньої появи. На нашу думку, є всі підстави вважати, що названі прізвищеві номени пов'язуються з чоловічим ім'ям Олександр (гр. Alexandros < alexō - «захищаю, допомагаю» i anēr (andros) - «чоловік», тобто «захисник людей»), яке на українському грунті зазнало найрізноманітніших модифікацій (пор.: Олесь, Лесь, Лесько, Лесик i т. ін.), а останні сприяли появі цілої низки антропонімічних назв (Лесевич, Лесенко, Лесечко, Лесик, Лесинчук, Лесич, Лесииин, Лесів тощо).

Денаціоналізацію засвідчують і такі українські прізвища, які мають у своїй структурі суфікс зі значенням присвійності, «належності комусь / чомусь»: Ковальов, Кравиов, Олійников, Крамаров, Кушніров, Скрипников, Співаков, Павликов, Макаренков, Горбачов, Глушков, Зубков, Сердюков, Хрущзов і т. ін. Їхню українськість підтверджує дериваційна база. Так, скажімо, прізвища, у яких закодована інформація про відповідну професійну діяльність (Ковальов, Кравцуов, Олійников, Крамаров, Кушніров, Скрипников, Співаков), відображають особливості української лексичної (або словотвірної) системи (пор.: укр. коваль і рос. кузнец; укр. кравець і рос. портной; укр. олійник і рос. маслобойщик; укр. крамар і рос. лавочник; укр. кушнір і рос. скорняк, овчинник; укр. співак і рос. певец; укр. скрипник і рос. скрипач). На відміну від української, російська антропоніміка має у своєму розпорядженні прізвища на зразок Кузнецов, Портной, Скорняков, Овчинников, Певцуов, Скрипачев тощо. Денаціоналізація розглядуваних вище антропонімів відбувалася, імовірно, чи то через додавання суфікса -ов до твірних основ на зразок Коваль, Кравецьь, Олійник, Крамар, Кушнір, Співак, Скрипник чи то через так звану ретроспекцію - повернення до староукраїнських граматичних форм зі статусом присвійних прикметників, які вказували на належність тій чи тій людині (син Коваля = Ковалів син < Ковалевъ сынъ; син Кравияя = Кравців син < Кравьцевъ сынъ; син Крамаря = Крамарів син < 
Крамаров з сынт тощо (пор.: Київ [Кийів] < Кнев т город Кия). Після занепаду редукованих в абсолютному кінці слова (Коваяєв Z,

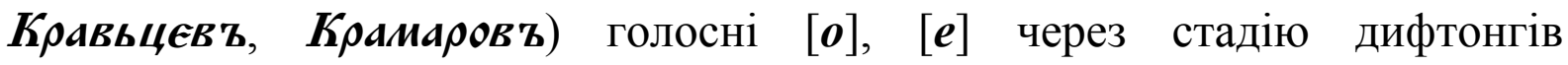
змінюються на $[\boldsymbol{i}]$. Звідси, відповідно, в українській антропоніміці представлені й такі номени, які відображають специфічно українські риси - Ковалів, Кравиів, Крамарів і т. ін. Слід зауважити, що в західноукраїнській традиції активно функціонують аналогічні прізвищеві найменування, дериваційною базою для яких послужили чоловічі імена: Іванів, Петрів, Марків, Федорів, Стецьків, Яиьків, Микитів тощо. До того ж представлені граматичні форми є спільними для носіїв чоловічої та жіночої статі: у першому разі вони $\epsilon$ відмінюваними, ілюструють чергування [i] 3 [o] у закритому / відкритому складах; у другому залишаються незмінними (пор.: Стеиьків Іван, Стецьков $\underline{a}$ Івана, Стецькову Іванові і т. ін.; Стецьків Надія, Стецьків Надї, Стецьків Надії і т. ін.; рос.: Иванов - Иванова; Петров - Петрова і т. ін.).

Прізвища на зразок Павликов, Макаренков, Горбачов, Глушков, Зубков, попри формальні показники - суфікси -ов засвідчують українське коріння, адже їхня структура маніфестує й специфічно українські ознаки, як-от: $\quad-и к$ (Павликов $\leftarrow$ Павлик $\leftarrow$ Павло), -енк $(о)$ (Макаренков $\leftarrow$ Макаренко $\leftarrow$ Макар $),-$-ч (Горбачов $\leftarrow$ Горбач $\leftarrow$ горбач $\leftarrow$ горбатий «який має горб» (пор. рос.: горбун $\rightarrow$ Горбун $\rightarrow$ Горбунов), $-\kappa($ Глушков $\leftarrow$ Глушко $\leftarrow$ Глухий $\leftarrow$ глухий - «який позбавлений слуху» (пор. рос.: глухой

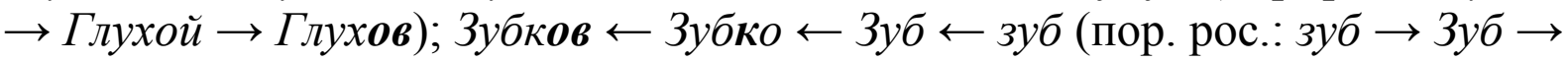
Зубов). Можна 3 упевненістю констатувати: носій модифікованого прізвища Сердюков - етнічний українець, на що вказують і словотвірні (суфікс -юк), і семантичні особливості (пор.: сердюк - «на лівобережній Україні в кінці XVII - на початку XVIII ст. козак найманих піхотних полків, що був на повному утриманні гетьманського уряду; охоронець гетьмана»). Проте дискусійним залишається питання про походження прізвища Козаков, адже, як відомо, козаками в Україні (XV-XVIII ст.) називали «вільну людину з кріпосних селян або міської бідноти, що втекла на південні землі України та брала участь у визвольній боротьбі проти татаро-турецьких і польських загарбників», а в Росії (XVI-XVIII ст.) «вільну людину з тих же таки кріпосних селян або міської бідноти, яка втекла на окраїни держави»; у дореволюційній Росії з XVIII ст. такий звуковий комплекс почали використовувати для означення «представників військового стану, уродженців військових областей, який повинен був служити в армії за пільгове користування землею». 3 огляду на хронологію можна допустити, що прізвище Козак (похідні Козаченко, Козачук і т. ін.) зародилося в середовищі українських козаків, а форма Козаков $є$ денаціоналізованою (пор.: син Козака = Козаків син $<$ Козаковъ сынъ). Подекуди аналізований антропонім вирізняється ще однією фонетичною особливістю, яка засвідчена в історії розвитку української мови, однак до 
сьогодні не знаходить задовільного пояснення. Ідеться про зміну [o] в [a],

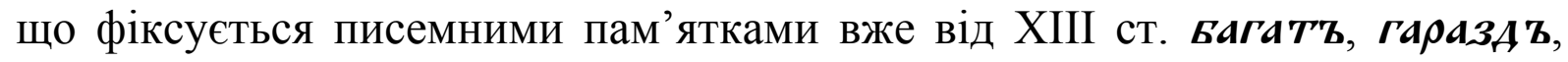
гарячь $($ колачь $\rightarrow$ калач; холява $\rightarrow$ халява; кожанъ $\rightarrow$ кажан; чованъ $\rightarrow$ чабан тощо). Такі риси відображені і в антропонімічних номенах (Кажан, Чабан, Чабаненко, Халявський, $з$ одного боку, і $з$ іншого, - Богацький, Богачевський, Богаченко, Богатинський т. ін.). Не є загальноприйнятною думка про так звану гармонійну асиміляцію або вплив південноросійського акаючого наріччя чи білоруської мови, оскільки в подібних ситуаціях багато слів такої асиміляції не знає (лопата, собака, козак).

Дериваційною базою для антропоніма Хрущзов, цілком очевидно, послужило прізвисько Хрущ, співвідносне з лексемою хрущ - «жук родини пластинчатовусих, що має червоно-буре забарвлення; шкідник лісу й саду; перен. мала дитина, людина», якій у російській мові відповідає звуковий комплекс майский жук.

Щоправда, значна частина антропонімічних назв із суфіксом -ов позбавлена чітких диференційних ознак, що дозволяли б встановити належність роду їхнього носія до того чи того етносу. Наприклад, прізвище Андріанов утворилося від чоловічого імені Андріан, запозиченого зі старослов'янської мови Анъдюнанz, спродукованого внаслідок контамінації Анъдрен + Ддрнонъ (останне бере свої витоки від латинського Hadriānus - «(г)адріанець, мешканець міста) (Г)адрії біля Адріатичного моря в Італії (Hadria - ім'я одного з римських імператорів (117-138 рр. н.е.), що походив із цього міста). Староукраїнською мовою «син Андріана» звучало як Андюнанов z сынъ; після занепаду редукованих відповідно до закономірних фонетичних процесів стабілізувалося Андріанів син $\rightarrow$ Андріанів. Поява прізвищевого найменування Андріанов свого часу була спричинена відповідною державницькою політикою та відповідною громадянською позицією конкретного носія (носіїв).

Денаціоналізація та невідповідність нормам українського правопису маніфестується й такими прізвищами, як Бєлозор (Бєлозір), Бєлоус, Бєлоусенко, Бєліков, Лисогор, Рябоконь, Рябовол, Черновол, Черноус, Чеботарь, Чеботарьов, Чеботаренко і т. ін. У своїй структурі вони містять виразні формальні показники того, що зародилися в україномовному середовищі. По-перше, більшість із них є композитними утвореннями, що відображає специфіку українського іменотворення, пов'язаного передусім 3 періодом козаччини; по-друге, показником українськості русифікованих прізвищ на зразок Білоусенко, Білик, Чоботаренко є наявність суфіксів -енк(о), -ик; по-третє, прізвища на зразок Чоботар, Чоботарів, Чоботаренко спродуковані на основі такої дериваційної бази, яка в російськомовному середовищі має зовсім інше звукове оформлення (пор. укр.: чоботар і рос. сапожник). При реєстрації відповідних антропонімів не враховувалися такі особливості: 
1) староукраїнський дифтонг [ie], який позначався літерою $\mathbf{k}$, змінився на українському грунті на $[\boldsymbol{i}]$ (пор.: $\mathbf{6} \mathbf{k} \mathbf{ы} \boldsymbol{~}>$ білий; $\mathbf{A t c z}>$ ліс; $\mathbf{A} \mathbf{k} \mathbf{z} \mathbf{z}>$ дід; $\boldsymbol{\pi} \mathbf{k} \mathbf{z k z}>$ пісок), на відміну від російської мови, де на місці t з'явився голосний [e] (бельй, лес, дед, песок) (пор. укр.: Білик, Білеиький, Білоус, Лісник, Залісний, Дідик, Дідич, Піщаний і рос.: Бельій, Белов, Лесков, Дедов, Песков). Останні згідно з нормами української орфографії записуються як Бєлий, Бєлов, Лєсков, Дєдов, Пєсков;

2) специфічно українською рисою $\epsilon$ чергування $[\boldsymbol{o}],[\boldsymbol{e}] \quad 3 \quad[\boldsymbol{i}]$ в новоутворених закритих складах на зразок кінь - коня, віл - вола, зір зору, гора - гір і т. ін., зумовлене занепадом редукованих (староукр.: конь коня, волz - вола). Дотримання правил чергування поширюється як на загальні, так і на власні назви і виявляється при словозміні найменувань осіб чоловічої статі (Білозір - Білозора, Лисогір - Лисогора, Рябокінь Рябоконя, Сивокінь - Сивоконя, Чорновіл - Чорновола, Кривоніс Кривоноса і т. ін.);

3) зміна давнього $[\boldsymbol{e}]$ в $[\boldsymbol{o}]$ після шиплячих та $j$ відбулася за умови, якщо в наступному складі був голосний непереднього ряду, тобто такий, який не пом'якшував попереднього приголосного (пор.: шестын - шостий; женатын - жонатий; пшено - пшоно; чернын - чорний і т. ін., але шестн - шести; женнтн - женити; пшєннца - пшениця; чернь - чернь); звідси й Чорновіл, Чорноус, Чоботар, Чоботаренко, але Пшеничний, Черняхівський, Черненко;

4) депалаталізація приголосних, передовсім шиплячих та дрижачого $[\boldsymbol{p}]$, у результаті якої останні втратили здатність бути м'якими в позиції кінця складу (слова), а відтак м'який знак після них не пишеться: Кобзар, Токар, Скляр, Школяр, Чоботар, Галич і т. ін.; останні, натомість, завдяки «зусиллям» працівників соціальних служб отримують русифікований варіант на зразок Кобзарь, Токарь, Чоботарь тощо. Зайві графічні знаки доволі часто трапляються в денаціоналізованих українських прізвищах: Ульянченко, замість Улянченко $\leftarrow$ Улянко $\leftarrow$ Улян; Ульянич замість Улянич $\leftarrow$ Улян; Касьяненко замість Касяненко $\leftarrow$ Касян; Дьченко (або Д’яченко) замість Дяченко $\leftarrow$ дяк; подекуди з'являється не характерне для української мови в таких ситуаціях подвоєння (Луппа, Салло);

5) прізвища прикметникового походження мають в українській мові закінчення -ий (-iй) (для осіб чоловічої статі), - $a$ (для осіб жіночої статі): Білий, Біла; Повний, Повна; Довгий, Довга; Останній, Остання. Така закономірність зберігається й при написанні українською мовою російських прізвищ: Бєлий, Горький, Крайній; Бєла, Горова, Крайня [7, с. 112]; написання на зразок Бєлая, Полная, Долгая суперечить нормам української орфографії навіть за умови, що носії цих прізвищ $є$ етнічними росіянами. Етнічний українець (українка) мають прізвищуватися Білий, Біла; Повний, Повна; Довгий, Довга. Останні чотири ілюстрації демонструють таку специфічно українську фонетичну особливість, як 


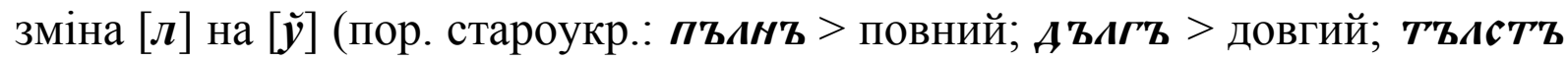

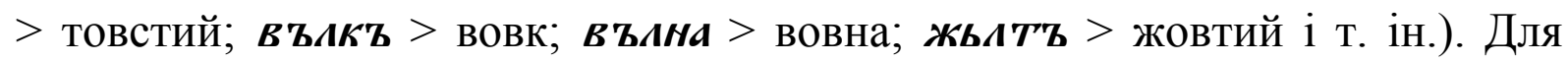
російської мови такі модифікації не характерні, а відтак - Толстой, Волков тощо.

Наведені розмірковування $є$ лише одним із акцентів тієї важливої проблеми, яку ось уже впродовж багатьох десятиліть намагаються розв'язати як вітчизняні, так і зарубіжні ономасти. Чи буде колись наведено порядок в українській антропоніміці - питання риторичне. Адже цілий ряд суб'єктивних і об’єктивних чинників, які стають на заваді нормалізації, уніфікації прізвищевих найменувань. Незаперечним залишається одне: історія нашого прізвища - історія нашого роду, а всі вони загалом складають літопис українського народу.

\section{Література}

1. Великий тлумачний словник сучасної української мови / [упорядн. та гол. ред. : В. Т. Бусел]. - К.; Ірпінь : ВТФ «Перун», 2001. - 1426 с.

2. Етимологічний словник української мови : у 7-и томах / [упорядн. : Болдирєв Р. В., Коломієць В. Т., Лукінова Т. Б. та ін.]. - К. : Наукова думка, 1982. - Т.1. -631c.; 1885. - T.2. - 570c.; 1989. - T.3. - 552c.; 2003. - T.4. - 656c.; 2006. T.5. $-704 \mathrm{c}$.

3. Історична граматика української мови : [підручник] / [Безпалько О. П., Бойчук М. К., Жовтобрюх М. А. та ін.]. - [2-е вид., випр.]. - К. : Радянська школа, 1962. - 510 c.

4. Півторак Г. Українці: звідки ми і наша мова? / Григорій Півторак. - К. : Наукова думка, 1993. - 200с.

5. Пономарів О. Культура слова : Мовностилістичні поради / Олександр Пономарів. - К. : Либідь, 1999. - 239 с.

6. Трійняк I. І. Словник українських імен / Іван Іванович Трійняк. - К. : Довіра, 2005. - 509 c.

7. Український правопис / АН України, Ін-т мовознавства ім. О. О. Потебні; Інститут української мови. - [4-е вид., випр. і доп.]. - К. : Наукова думка, 1993. - 240 c. 